\section{An Investigative Look at Healthcare Beliefs and Practices During the Sen Dynasty}

\section{Dave Beine}

\section{Abstract}

There is not much known about Nepal during the historical period sometimes referred to as Nepal's dark ages (750-1750 C.E.). And even less is known about the healthcare practices of the Sen Dynasty of Palpa, Nepal, which found its inception over 500 years ago, during the late fifteenth century. For this reason, anyone endeavoring to intelligently write on the subject must, much like an archaeologist, use a bit of educated conjecture to piece together a speculative, but historically plausible, picture of the healing practices likely employed during that period. In order to do so, this paper examines several pieces of evidence, both historic and contemporary, in order to infer what the healthcare practices of the populace of Palpa might have looked like at that time.

Keywords: Sen Dynasty, Healthcare, Palpa, Nepal, Magar Culture

\section{Introduction}

The Sen Dynasty of Nepal had its inception in the late fifteenth century during the historical period sometimes referred to as
Nepal's dark ages ${ }^{1}$ (750-1750 C.E.). Relatively little is known about Nepal during that era, and even less is known about the healing practices being actively employed among the populous of the Palpa kingdom during that time. For this reason, anyone endeavoring to intelligently write on the subject must, much like an archaeologist, use a bit of educated conjecture in order to piece together a picture of the likely past healing practices. In order to do so, this paper examines several evidences, both historic and contemporary: 1) the available literature on healthcare practices among the Rajputs-- the root from which the Sen Dynasty first sprang (during the centuries preceding and corresponding to the Sen Dynasty's entrance into Nepal), 2) available historical evidence regarding healthcare practices of the then-contemporary Shah Dynasty (a hereditarily related and intermarrying branch off the same Rajput root), 3) historic healthcare practices of the local majority (and intermarried) Magar community, which likely would have impacted the healthcare of the inhabitants of the kingdom, Magar and non-Magar alike and 4) contemporary healthcare practices still observed today among the populace of Palpa (inferring that some of what we see practiced today, by the modern descendants of the earlier inhabitants, likely has its origin in earlier practices). In short, combining history and knowledge of the Rajput's earlier medical practices, the practices of hereditarily and matrimonially related dynasties, coupled with what we see practiced by their modern descendants, we should be able to speculate, with some level of confidence (much like an archeologist using living related cultures to draw inferences regarding older cultures), about the health practices likely being employed by the populous of Palpa during the time of the Sen

${ }^{1}$ Although many authors, including myself (Beine 2003:32), refer to this as the dark ages because of the supposed dearth of historical information available from this period, my research (due to my inability to read Nepali fluently) has mainly been limited to English language manuscripts. There is probably other literature on the subject that might be discovered in the historical archives of Nepal, but this information is in Nepali and thus, largely inaccessible to those of us not fluent in reading Nepali. This is a self-admitted weakness in this essay. For this reason I encourage Nepali sociologists and historians to research the topic more thoroughly in an attempt to fill the gap in our knowledge in this important matter. 
Dynasty. What emerges is a speculative, but historically plausible, picture of their health practices.

\section{Healthcare among the Rajputs - Ayurveda and allopathic precursors}

The first bit of evidence we can examine to speculate on healthcare practices during the Sen Dynasty is information gathered about the Rajputs of India during the centuries preceding and corresponding with the Sen Dynasty's immigration to Nepal. Although there is some dispute as to the origin of Nepal's Sen Dynasty, ${ }^{2}$ popular historical opinion claims their origin (along with that of the Shah Dynasty) as members of the Sisodia clan of Suryavanshi Rajputs of Chittor, Rajasthan. So, what do we know about the healthcare of the Rajputs from which the Sen Dynasty supposedly sprang? King Bhoj, a Rajput who ruled from 1010-1060 C.E., is well known for his extensive writings on medicine (Kapur 2010: 366). The Rajputs were Hindus (Kapur 2010: 365) and among the greatest contributions to medicine made by the Hindus of medieval India is Ayurveda (Haidar 2008). Ayurveda (the science of long life), the oldest of the Indian medical traditions, is highly developed with its own doctors, hospitals and medical texts, and depends principally upon non-invasive herbal treatments. Ayurveda is extremely popular throughout Nepal today and there are several Ayurvedic clinics and pharmacies currently in Tansen, ${ }^{3}$ suggesting at least preliminarily, that Ayurveda likely came with the Rajputs from India and was one popular form of medical treatment during the Sen Dynasty.

Although subsumed under the category of Ayurveda, the early medical practices of ancient India certainly overlap with concepts and practices of modern allopathic medicine. The Shusruta Samhita, a one-thousand page medical text completed during that

\footnotetext{
${ }^{2}$ A recent book by Subodh Kumar Singh (2007) claims that the Sen Kings of Nepal were actually Tharu rather than Rajputs.

${ }^{3}$ There is one district-level Ayurvedic Dispensary in Tansen and six ilaka-level Ayurvedic Dispensaries in the district.
}

\section{$64 \mid$ Dave Beine}

era, describes surgical instruments, surgical procedures and even dressings (Kapur 2010:430). Kapur writes that "Shusruta describes eight types of surgery: extracting tumors, excision, incision, probing, scarification, puncturing, evacuating fluids and suturing," and from the sixth century C.E. onward, in India, "limbs were amputated, abdominal sections were preformed, fractures were set, hemorrhoids were removed, and cesarean section was done” (2010: 430). Over 1100 specific diseases were enumerated by scholars at that time (Kapur 2010: 431) and diseases were categorized into eight types - lymphatic diseases, blood circulation problems, cell disorders, tissue problems, skeletal system problems, bone marrow disorders, hormones disorders and digestive organ diseases (ibid). Diagnostic methods included listening to the chest and abdomen, and checking the pulse and tongue (practices still common in modern allopathic medicine today). There are various other medical volumes from this era that describe the functions of the heart and the circulatory system (ibid), specialized treatments for eyes and head, and other specializations in the areas of toxicology, therapeutics, pediatrics, reproductive issues, pharmacology, and mental illness (Kapur 2010: 432). And there seemed to be already an initial understanding of germ theory by the eighth century C.E. Kapur writes "Charaka describes twenty types of disease-causing germs, some of them reside outside the body some others reside inside the body" (2010: 432). Beyond this, vaccinations, hospitals, and concepts of sanitation were already familiar concepts (Kapur 2010: 435) and Kapur claims that the roots of modern allopathic medicine can be traced to India (2010: 437). Apparently medicine was quite developed in ancient India at the time when the Rajputs would have inhabited Rajasthan. And so it is likely that the Sen Dynasty would have arrived to Palpa employing the various Ayurveda and allopathic healing technologies developed during the eras of their Rajput predecessors.

\section{From Rajasthan to Nepal}

The Muslim invasion into Rajasthan between the twelfth and sixteenth centuries began to slowly push Rajputs north. Sisodia Rajputs, who inhabited Udaipur in Rajputna, then continued fleeing north under increasing Muslim pressure, entering the 
Gharwal and Kumaon regions of Northern India and finally into western Nepal by the late fifteenth century (Kasajoo 1988). As the Rajputs entered western Nepal they began to take shelter in the hilly areas, where many founded their own little hilltop principalities. Among this migration were the Sens and the Shahs who both trace their common ancestry to this Sisodia line of Rajputs. Khem Sen and Ram Sen founded a small kingdom at Butwal (exact dates unknown), while their descendant Rudra Sen (who ruled from 1483-1518 C.E.) entered the Madi Valley, founding his kingdom at Tansen, in the heart of what was then the western Magar state of twelve magarants (12 small principalities that made up one federation). The Shahs continued on to Gorkha, the vantage point from which they would later unify Nepal as a single kingdom. Rudra Sen of Tansen arranged the marriage of his first son, Mukunda (who ruled from 1518-1553 C.E.) to the daughter of the Magar chief of Baldengadhi; thus Magar blood entered the line of the Sen Dynasty (which would later enter the line of the Shah Dynasty, through marriage, into the royal lineage of Nepal).

\section{Healthcare among the Shah Dynasty}

There is little available in the written record about healthcare practices in Palpa during the time of the Sen Dynasty. Hence, I want to examine the healthcare practices (at approximately the same time in history) among a genetically and matrimonially related clan (The Shahs). Fortunately, much more is known historically about the Shahs (who became the ruling monarchs of modern Nepal) and it is safe to assume that a shared genetic heritage (through the Sisodia line of Rajputs) combined with a pattern of regular intermarriage between the two dynasties would likely produce similar cultural patterns, such as similar healthcare beliefs and practices.

According to historians, the modern affinal (through marriage) kinship ties between the Sen and Shah dynasties began when the daughter of Gandharva Sen married Nara Bhupal Shah in 1717 C.E. (Kasajoo 1988:10). Prithvi Narayan Shah (the future unifier

\section{6 | Dave Beine}

of modern Nepal) was the offspring of this union. Kasajoo (1988:10) comments that Mukunda Sen II was his cousin "and they had good relation.” Later, Prince Bahadur Shah, in an effort to improve relationships with the Palpa dynasty, married the daughter of Mahadatta Sen in1790 C.E. (Regmi 1973:6), further strengthening ties between the two dynasties. This second marriage led to an alliance between Palpa and Gorkha which subsequently led to the military expansion of Nepal (including the western states of Nepal and the Kumaon and Gharwal regions of modern India). Among these western Nepali states was Palpa, annexed into the larger kingdom in 1806 C.E. This Shah/Sen Dynasty lasted until the beginning of the Rana regime in 1846 C.E. It is clear that there was much matrimonial interaction, from start to finish, during the time of the Sen and Shah dynasties, which implies there would have been frequent and regular contact between these two family lines.

So, what is known of the medical practices during the Shah/Sen period? According to Dixit (2005:5), allopathic (western) medicine has been known among the Kathmandu Rajas since about 1740 C.E. And in specific reference to the Shahs, he writes, "The first reference to the modern system of medicine or to allopathic practitioners in this country occurs in an account of the siege of Kirtipur by King Prithvi Narayan Shah in 1766/67.” According to Dixit, "It was Swarup Ratna, the King's brother, who had been cured of a wound by one Michael Angelo, a Capuchin monk. Other sources identify the one wounded as Prince Pratap, Shah of Gorkha.” Dixit mentions one more historical account of the use of allopathic medicines by the Kathmandu Rajas in 1777 C.E., and then suggests that allopathic medicine was removed from Nepal (along with the missionaries who brought it) until mid-way through the twentieth century. Hence, it is likely that members of the Sen Dynasty had some knowledge of (and maybe limited access to) allopathic medicine during the final hundred years of the dynasty, although it is uncertain what impact this may have had upon medical practices in the Sen Homeland of Palpa. 
The Sen Dynasty officially came to an end in 1846 C.E. with the beginning of the Rana regime. If we look at the healthcare practices at the beginning of the Rana regime, we can add to our understanding of what might have been happening in regards to healthcare practices among the populace of Palpa near the end of the Sen Era as well. Dixit (2005:9-12) lists several examples of Jung Bahadur Rana's preference for and use of allopathic medicine. Bir Shumsher (Jung Bahadur's youngest brother) succeeded Jung Bahadur, becoming Prime Minister in 1885 C.E. Bir Shumsher had many experiences with various forms of medicine. In 1884 C.E. he had been successfully allopathically treated for colic. In 1890 C.E. he built the first allopathic hospital: Bir Hospital. He invited a number of well-known doctors to Nepal during his tenure. He opened a number of other allopathic health facilities, including leprosy and cholera hospitals, across the country. And he is known to have employed various nonallopathic forms of medicine as well. After attempting a conspiracy against Bir Shumsher, Khadga Shumsher (his relative) was exiled to Palpa where he served as "governor" and was allowed to rule this smaller principality, in submission to Kathmandu (Kasajoo 1988:13). So, it is possible that Bir Shumsher's positive outlook on allopathic medicine influenced the line of Shumsher governors of Palpa, at the end of the Sen Era.

\section{Historic healthcare among the Magar}

Thirdly, we will look at the historic healthcare beliefs and practices of the ethnic Magar tribe at the time of the Sen Dynasty. The Magars were the principle inhabitants (population-wise) of the Sen Kingdom of Palpa District, so their beliefs and practices would likely have had a strong influence on healthcare beliefs and practices employed throughout the kingdom at that time. What do we know about the Magars and their beliefs during the Sen Dynasty? First of all, there is no doubt that the Magars of Palpa District have been heavily "Hinduized" throughout the centuries. Lecomte-Tilouine (2009:61) claims that it was the "Thakuri petty kings" who first initiated this process beginning in the fifteenth century. She states, "The Magar people were quickly assimilated, adopting most of their Hindu neighbours' cultural traits, notably their language and religion.” Even so, she concludes (in relation to a particular Hindu deity formerly neglected by Hindus but important to the Magars) that they "retained or developed particular rituals." These rituals complied with Hinduism at the surface-structure level, but they were either syncretistically combined with pre-existing Magar beliefs (constructing a new hybrid Magar meaning at the deep-structure level) or they were appropriated as a sort of anti-hegemony cultural invention that was useful to "defend their rights... in the face of Hindu invaders"(Lecomte-Tilouine 2009:61-62 ). Either way, the important thing to note in respect to the topic of healthcare, is that even though the Magars were "Hinduized," various elements of their culture (such as the importance of spirits, related to the domain of sickness and healing in Magar cosmology) were retained and incorporated. As we will see subsequently, such cultural influence seldom goes just "one-way." These Magar beliefs were likely influential on the health beliefs and practices of all the people in Palpa (the majority being Magar) during the Sen Dynasty. And, as we will see in the final section of this paper, it appears that Magar beliefs and practices are still influential in the healthcare beliefs and practices of the populace of Palpa today.

From the earlier sections of this paper (i.e. the focus on the Rajput Hindu origin and relation to other Rajput Hindu dynasties), one might get the false impression that the Sen Dynasty was an Aryan dynasty. While it is certainly true that the Sens sprang from Aryan Rajput roots, later scholars have begun to elucidate our understanding, alerting us to the fluidity of the concept of race and ethnicity here in Nepal, particularly as it relates to the Sen Dynasty. I have already discussed the early affinal ties between the Sen and Magar kings. Lecomte-Tilouine (2009:92) further claims, "King Mukunda Sen was assimilated to the Magars, who formed the majority of his subjects. He did have some Magar blood in him as his ancestor, Abhaya, had married the daughter of the Magar king of Makwanpur... Moreover, one of Mukunda Sen's wives was the daughter of the Magar king of Parkogha." She notes that in a manuscript dated 1510 C.E., "Mukunda Sen is described as a Magar king of Palpa who invaded the Kathmandu Valley in 1518” (2009:93). 
Later Lecomte-Tilouine goes on to explain how the Magars also had great influence upon the Shah dynasty. She comments that, "Prithvi Narayan Shah came to rely heavily upon the Magars, who formed an important part of his troops." Likewise she mentions that the first king of modern Nepal demonstrated confidence in the Magars by entrusting a Magar as his sword holder, and the man considered by the king to be most holy in Gorkha was also a Magar (2009:94). She states that in his memoirs, "Prithvi Narayan Shah recalls his Magar dada, the man who looked after him during his childhood, and declares himself 'the king of Magar country'” (2009:94). These findings lend more credibility to my earlier connection (and hypothesis of cultural extension) between the Sen and Shah families.

In relation to healthcare, Lecomte-Tilouine draws an historic picture among the Magar where sickness and health beliefs, and practices, were once the exclusive domain of the spirits. She infers a close relationship between humans, health and the spirits when she describes the Magar belief that "the spirits provoke disease in men" (2009:18). She traces the earliest historic account of this belief to a text (a Magar folktale) written in 1899 by an Ayurvedic doctor named Girishavallabha Joshi (Lecomte-Tilouine 2009:31) claiming the text "brings some historical depth to our knowledge of the Himalayan religions" (i.e. Magar and related groups). From this historic text she documents the fictional semi-spirit hero's marriage to the daughter of King Mukunda Sen of Palpa (2009:44), who would be the grand-daughter of the Magar chief Baldengadhi (see above "From Rajasthan to Nepal"). Thus, the strong tie between spirits and the Sen Dynasty is made evident, as well as the strong tie between the spirits and illness.

Elsewhere in the story, according to Lecomte-Tilouine (2009:54), we see "Suna Jhankri takes Ban Jhankri's (both semi-spirit shamans) pulse in order to treat him (although he uses Ayurvedic drugs after diagnosis).” Here we see the pluralistic use of Magar beliefs (spirits are involved), allopathic medicine (the pulse leading to diagnosis) and Ayurvedic medicine (the treatment), which might have been characteristic of medical practices during the Sen Dynasty.

Drawing on the similarities noted in ethnographic writings among Western Magars of other places (e.g. Lecomte-Tilouine 2009), other geographically disparate Magar groups such as Eastern Magar (e.g. Hitchcock 1966 and Shepherd 1982), more distantly related Magar groups such as Kham Magar (e.g. Watters et. al. 2011), and other even more distant culturally-related groups such as the Chepang (e.g. Beine, Caughley and Shrestha 2012), one could infer with some degree of confidence (based on the principle of cultural diffusion) what the healthcare practices of the Magars of Palpa might have been during the Sen Dynasty. For the sake of brevity, I will not go into each of these here; rather I will state that there is a great deal of remaining similarity in the customs among these groups, which will be described in the final section of this paper.

The influence of culture certainly went both ways. Magar cultural practices related to sickness and health likely had an influence on the populace of Palpa during the Sen Dynasty. They certainly have influence today, as will be seen in the next section.

\section{Modern health practices among the Magars of Palpa}

The final bit of evidence that we can use to surmise the healthcare beliefs and practices of the Sen Dynasty is contemporary culture. Much like an archeologist who uses living related cultures to infer backward upon the culture s/he is investigating (referred to in archaeology as "ethnographic analogy"), we can use what we know of current medical practices among the populace of Palpa to add strength to our earlier inferences about medical practices during the Sen Dynasty. If the people of current day Palpa (and other related but geographically disparate groups) are still practicing certain traditions, then it is likely that these have persisted from earlier times. For this reason, in this final section I will be looking particularly at Magar customs related to illness and healing, which 


\section{2 | Dave Beine}

are still practiced in Tansen, Palpa. I conclude that these practices of today are a living relic, likely reminiscent of past customs practiced during the Sen Dynasty.

Because the Magars follow a shamanistic tradition, there are very few temples associated with their deities. Instead there are many sacred places where particular rituals, acts of worship and supplication regularly occur. Below is a list of several living Magar customs or rituals (related to sickness and health) which I have documented as still being practiced among Magars of Tansen, Palpa today.

- Worship of deceased ancestor spirits called pitri is conducted yearly. As part of the ceremony, nine leaf plates of various items are prepared (a tenth is prepared for the officiating Brahman). This ritual is usually conducted at the yearly anniversary of the death of a family member and is believed to serve to keep the spirits of the deceased from causing sickness in the family. There are various other malevolent spirits (former humans) who must also be appeased to keep people healthy. One is called a baiv who wanders the earth and can cause sickness. Another is known in Palpa are ledine (the spirit of a woman who died in childbirth). Yearly sacrifices (usually a cock for a man and a hen for a woman) are still conducted to appease these malevolent spirit beings.

- Ghar paisa ceremony is conducted to appease a male deity who comes to live in the kitchen of a newly built house. The deity is a family deity who looks after the health of all family members, their animals and their crops. This deity is propitiated each year through the sacrifice of a cock promised the year before.

- A healer referred to as a "lama" (although he is not Tibetan) is often consulted in the case of sickness.
Sickness is seen as a spiritual problem, not physical. In one of the lama's treatments, the patient must drink a liquid concoction supposedly comprised of various ground up pieces of human and animal bone, teeth, tongue, intestines, etc.

- In request for recovery from illness, people construct small alters to various deities at a place where the deity is believed to reside. A small shrine is constructed using cow dung, water and several flat rocks to make a small room. One rock is then selected to represent the deity and "clothed" with a stone and placed in the center of the room. Various sacrificial foods, such as puffed rice, cow's milk, rice flour fried in ghee, etc., are offered to the deity. The shrine is then further adorned with bits of colored fabric, flowers, a small copper oil lamp (with mustard oil inside), turmeric, etc.

These are but a few customs related to sickness and healing being contemporarily practiced among the Magar of Palpa today (confirmed through personal interviews). By way of ethnographic analogy, we can infer that these (or very similar) customs were a daily part of the healing beliefs and practices of the Sen Dynasty, particularly because of the strong influence of Magar culture upon the Sen Dynasty, as I have alluded to earlier.

One final note on Magar health beliefs: Magar beliefs and practices regarding health and healthcare are most often subsumed under the cultural domain of religion. And religion is one of the most tenaciously held aspects of culture. Therefore one would expect these Magar religious-based healing beliefs to persist even as other parts of culture are being absorbed into the wider culture.

\section{Conclusion}

In conclusion, combining history and knowledge of the Rajput's earlier medical practices, the practices of hereditarily and 
matrimonially related dynasties, coupled with what we see practiced by their modern descendants, allows us to speculate, with some level of confidence, upon the health practices likely being employed by the populous of Palpa during the time of the Sen Dynasty. A picture is painted of a society that likely had access to (and practiced) a variety of pluralistic medical behaviors, from the Rajput-influenced Ayurvedic and allopathic precursors and the Shah-influenced allopathic methods to the traditional healing practices of the dominant Magar populations of Palpa District. Although certainly speculative, our investigation of the cultural roots of the Sen, related dynasties, and our ethnographic analogy approach of studying the dominant Magar culture, leaves us a plausible picture of healthcare beliefs and practices during the Sen Dynasty.

\section{References}

Beine, David, Ross Caughley and Dwarika Shrestha. (2012). Chepang Then and Now: Life and Change Among the Chepang of Nepal. Blurb Books.

Beine, David K. (2003). Ensnared by AIDS: Cultural Contexts of HIV/AIDS in Nepal. Kantipath, Kathmandu, Nepal: Mandala Book Point.

Dixit, Hemang. (2005). Nepal's Quest for Health. Kathmandu, Nepal: Educational Publishing House.

Haidar, Mansura. (2008). Medical Works of the Medieval Period from India and Central Asia. Diogenes May 2008 vol. $55: 2(27-43)$.

Hitchcock, John T. (1966). The Magars of Banyan Hill, New York: Holt, Rinehart and Winston.

Kapur, Kamlesh. (2010). History of Ancient India (Portraits of A Nation). Sterling Publishers Pvt. Ltd.

Kasajoo, Vinaya Kumar. (1988). Palpa As You Like It. Tansen, Nepal: Kumar Press.

\section{4 | Dave Beine}

Lecomte-Tilouine, Marie. (2009). Hindu Kingship, Ethnic Revival, and Maoist Rebellion in Nepal. New York: Oxford University Press.

Regmi, Mahesh C. (1973). Palpa's Regulation with Nepal and Oudh. Regmi Research Series 5:1. Kathmandu, Nepal: Regmi Research (Private) Ltd.

Shepherd, Gary. (1982). Life among the Magars. Dallas, Texas: International Museum of Cultures.

Singh, Subodh Kumar. (2007). The Return of the Mauryas. Babita Singh Publishers.

Watters, David E. et. al. (2011). At the Foot of the Snows. Engage Faith Press. 